\title{
Lime Swallowtail, Chequered Swallowtail, Citrus Swallowtail Papilio demoleus Linnaeus (Insecta: Lipidoptera: Papilionidae) ${ }^{1}$
}

Delano S. Lewis ${ }^{2}$

\section{Introduction}

The lime swallowtail, Papilio demoleus Linnaeus, is sometimes called the chequered or citrus swallowtail. This butterfly ranges widely and is an extremely successful invader. Its proliferation appears to be aided by agricultural land use and urbanization that creates new, suitable open habitat and enhanced availability of host resources.

Papilio demoleus is native to the Old World where six subspecies are recognized. They are:

- P. d. demoleus,

-P. d. libanius Fruhstorfer,

-P. d. malayanus Wallace,

-P. d. novoguineensis Rothschild,

- P. d. sthenelus Macleay,

- P. d. stenelinus Rothschild.
Papilio demoleus sthenelus is found only in Australia and, along with the subspecies in Papua New Guinea, utilizes different host plants than the Asian and African subspecies. The population in the Dominican Republic has been traced to a southeast Asian subspecies (Eastwood et al. 2006). This species is also morphologically similar to Papilio demodocus Esper from Africa and Madagascar.

\section{Distribution}

This species is found throughout tropical and subtropical regions of southern Asia, ranging from Saudi Arabia, Iran and the Middle East to India, Nepal, southern China, Taiwan, and Japan, and south through Malaysia, Indonesia, and New Guinea to Australia. In recent years, $P$. demoleus has been recorded in the Dominican Republic, Puerto Rico, and Jamaica.

\section{Description}

Adults: The adults range in wingspan from 80-100 mm. The hindwing has no tail. The upper portion of the forewing is largely black and the outer

1. This document is ENY 444, one of a series of the Entomology and Nematology Department, Florida Cooperative Extension Service, Institute of Food and Agricultural Sciences, University of Florida. Original publication date January 2009. Visit the EDIS Web Site at http://edis.ifas.ufl.edu.

2. Delano S. Lewis, graduate research assistant, Department of Entomology and Nematology; Florida Cooperative Extension Service, Institute of Food and Agricultural Sciences, University of Florida, Gainesville, FL 32611.

The Institute of Food and Agricultural Sciences (IFAS) is an Equal Opportunity Institution authorized to provide research, educational information and other services only to individuals and institutions that function with non-discrimination with respect to race, creed, color, religion, age, disability, sex, sexual orientation, marital status, national origin, political opinions or affiliations. U.S. Department of Agriculture, Cooperative Extension Service, University of Florida, IFAS, Florida A. \& M. University Cooperative Extension Program, and Boards of County Commissioners Cooperating. Larry Arrington, Dean 
wing margin has a series of irregular yellow spots. Two yellow spots are present at the upper end of the discal cell with several scattered yellow spots in the apical region. The upper hindwing has a red tornal spot and the discal black band is dusted with yellow scales. The under side is paler yellow with the black areas more heavily dusted with yellow. The adults fly in every month but are more abundant after monsoons.

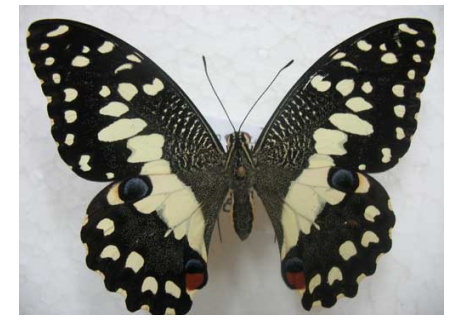

Figure 1. Adult - dorsal view

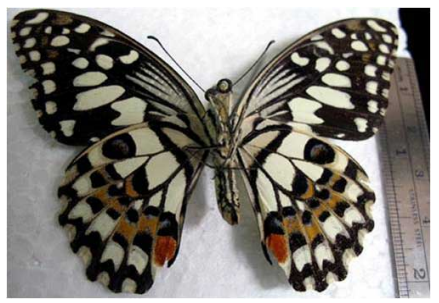

Figure 2. Ventral view

Eggs: The eggs are pale yellow, nearly spherical, about $1.5 \mathrm{~mm}$, basally flattened, and smooth. Females lay eggs singly near the edges of the food plant leaves.

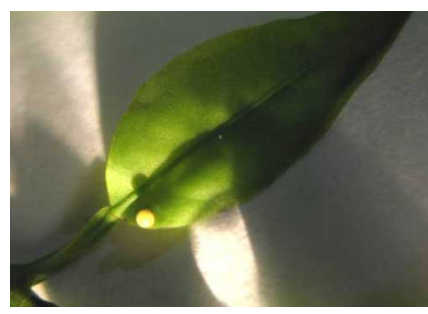

Figure 3. Egg

Larvae: First instars are black with a black head, with two sub-dorsal rows of short fleshy spines. Second, third, and fourth instars have a dark brown and glossy head capsule. The anterior, middle and posterior parts have broad transverse off-white bands, giving larvae a 'bird dropping' camouflage pattern. An additional row of paired fleshy spines occurs on the thorax. The head is brown, smooth and shiny, with short hairs.

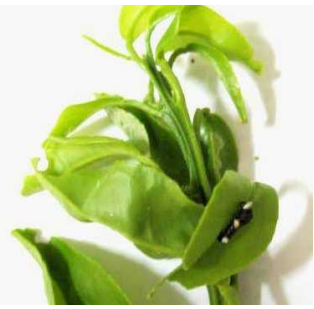

Figure 4. 1st instar

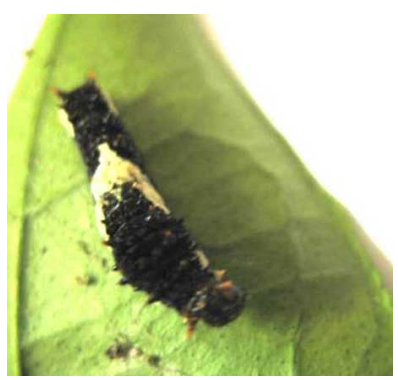

Figure 5. 1st instar - with v-shaped white mark

Fifth (mature) instars are cylindrically shaped and tapered anteriorly. The pair of fleshy spines located posteriorly and again immediately behind the head are very short, being initially yellowish-orange which gradually changes to green. They have rows of orange or pink spots that are edged with black laterally and subdorsally with additional black transverse markings located anteriorly, with more scattered black markings laterally and at the rear end. There is a white sub-lateral line along the abdominal area just above the legs. The fleshy spines are orange. The head is large and brown with a dull orange inverted $\mathrm{V}$ mark.

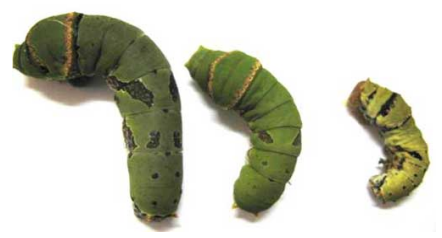

Figure 6. 3rd, 4th and 5th instars

The osmeterium is yellow at the base to orange at the tips. This fleshy, forked structure occurs just above the head on larvae of swallowtail butterflies. It is normally hidden but can be everted when the caterpillar feels threatened. It emits smelly compounds that deter some predators.

Pupae: The pupae are reasonably stout, rugose, and about $30 \mathrm{~mm}$ long. They are attached to the thicker stems of the food plant, or to adjacent sticks and rocks. The color is dimorphic, typical for many 


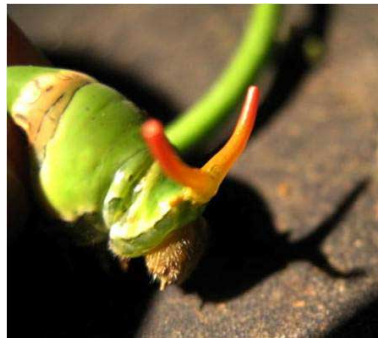

Figure 7. Osmeterium

swallowtails, being either pale green or pink-brown with other variable cryptic markings. The green form is usually marked dorsally with yellow. The color pattern imitates the dominant surrounding color to which the pupa is attached. The pupal duration is variable. In some areas, it is about 30 days in spring, reducing to 18 days in summer, but often those pupae formed in captivity during autumn will not produce adults until the following spring, or even longer with one record of 280 days.

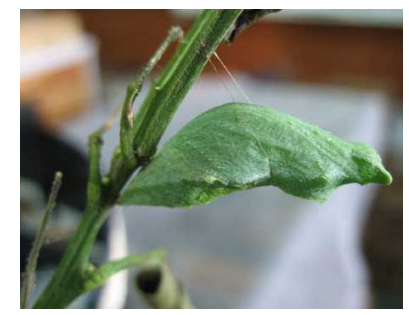

Figure 8. Pale green pupa

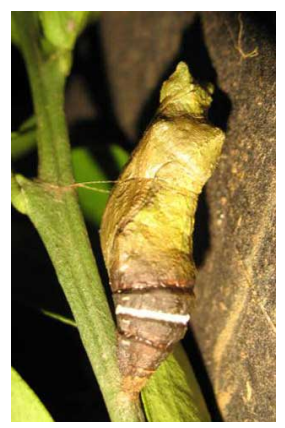

Figure 9. Pink-brown pupa showing white band

\section{Life Cycle}

This species typically has five instars and is capable of producing multiple generations per year depending on temperature constraints. Near the equator as many as nine generations may be seen. The average length of a generation varies from 26 to 59 days. In colder climates, pupae may overwinter.

\section{Hosts}

Outside of Australia and New Guinea, $P$. demoleus feeds on plants in the Rutaceae family. It is known to feed on virtually all species and varieties of native or introduced citrus (including cultivated members of the genus Citrus), Glycosmis pentaphylla (Jamaica mandarin orange), Ruta graveolens (Rue, common rue, herb of Grace), Aegle marmelos (Bael fruit, Bengal quince, elephant apple, golden apple, holy fruit), Murraya koenigii (Indian curry-leaf tree, curry-leaf tree, curry-leaf, curry leaves, Indian curry leaves, Karapincha), and Chloroxylon swietenia (East Indian satinwood).

Papilio demoleus has been observed ovipositing on Citrus aurantium (bitter orange), and Citrus aurantifola (Key lime, Mexican lime, West Indian lime) (Common and Waterhouse 1972, 1982; Tsukada and Nishiyama 1982; Larsen 1984; Braby 2000; Rafi et al. 1999a; Rafi et al. 1999b; Rafi et al. 1999c; Rafi et al. 1999d). The potential suitability of additional cultivated and native New World Rutaceae including plants in the genera Amyris, Ptelea, and Zanthoxylum is unknown.

The Australian and New Guinean populations feed on Fabaceae. They have been observed on species of Cullen (=Psoralea): Cullen australasicum (tall verbine), C. badocanum, C. balsamicum, $C$. cinereum, $C$. patens (spreading scurf-pea, native verbine), C. pustulatum, C. tenax (tough scurf-pea, emu-foot, emu grass), and C. leucanthum. They are also found on Soralea pinnata (fountain bush), and Microcitrus australis (Australian round-lime, Australian lime). They are known to oviposit on Rutaceae: Citrus aurantium (bitter orange), and Citrus aurantifola (Key lime, Mexican lime, West Indian lime).

\section{Economic Importance}

The New World arrival of this vagile lepidopteran pest is a potential threat to the citrus industries in the region. The larvae are a serious pest of citrus nursery stock (trees 1-2 ft. in height) and other young citrus trees in Asia and the Middle East, where they are capable of defoliating entire nursery groves. Larvae may utilize young leaf flush on more mature trees. 


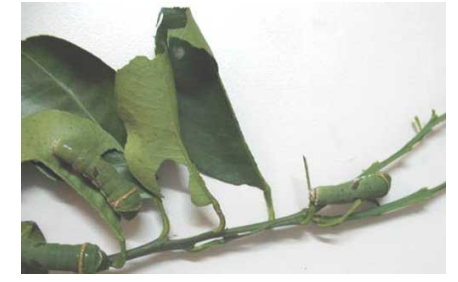

Figure 10. Host damage

\section{Management}

Biological control. Three parasitoids are known to parasitize $P$. demoleus larvae in India. They are Apanteles (=Ooencyrtus) papilionis, Apanteles sp. and Bracon hebetor (Hymenoptera: Braconidae).

In Thailand, two kinds of egg parasites were found: Ooencyrtus malayensis Ferriere (Hymenoptera: Encyrtidae) and Tetrastichus sp. (Hymenoptera: Eulophidae). A larval parasite, Erycia nymphalidophaga Baronoff (Diptera: Tachinidae), was found. Additionally, Brachymeria sp. (Hymenoptera: Chalcididae) and Pteromalus puparum Linnaeus (Hymenoptera: Pteromalidae) are pupal parasites. Other natural enemies of larvae found in Thailand were a predatory pentatomid bug, Cantheconidea furcellata (Wolff); reduviid bugs; birds; spiders; sphecids; and chameleons.

In Jamaica, an encyrtid egg parasitoid and a chalcidoid parasitoid have been reported.

The biopesticides Bacillus thuringiensis and Beauveria bassiana, as well as neem seed kernel extract and azadirachtin were shown to have effects on P. demoleus in India. Bacillus thuringiensis showed the highest effect.

Other natural methods of control. Larvae are easily hand-picked from nursery plants, but this practice is labor intensive if infestation is high.

\section{Selected References}

- Braby MF. 2000. Butterflies of Australia: Their identification, biology and distribution. Volume 1. CSIRO Publishing.

- Common IFB, Waterhouse DF. 1972. Butterflies of Australia. Angus and Robertson Publishers.
- Common IFB, Waterhouse DF. 1982.

Butterflies of Australia. Angus and Robertson Publishers.

- Eastwood R, Boyce SL, Farrell BD. 2006. The provenance of Old World swallowtail butterflies, Papilio demoleus (Lepidoptera: Papilionidae), recently discovered in the New World. Annals of the Entomological Society of America 99: 164-168.

- Garraway E, Murphy CP. Unpublished manuscript. First record of Papilio demoleus (the Lime Swallowtail) a potential pest of citrus, on Jamaica. Dated October, 2006.

- Guerrero KA, Veloz D, Boyce SL, Farrell BD. 2004. First New World documentation of an Old World citrus pest, the Lime Swallowtail Papilio demoleus (Lepidoptera: Papilionidae), in the Dominican Republic (Hispaniola). American Entomologist 50: 227-229.

- Heppner JB. (December 2006). Pest Alert: Lime Swallowtail in the Caribbean and possible impacts for Florida citrus. Florida Department of Agriculture and Consumer Services Division of Plant Industries. http://www.doacs.state.fl.us/pi/enpp/ento/ limeswallowtail.html (14 November 2008).

- Homziak MT, Homziak J. 2006. Papilio demoleus (Lepidoptera: Papilionidae): A new record for the United States, Commonwealth of Puerto Rico. Florida Entomologists 89: 485-488.

- Larsen TB. 1984. The zoogeographical composition and distribution of the Arabian butterflies (Lepidoptera; Rhopalocera). Journal of Biogeography 11:119-158.

- Rafi MA, Matin MA, Khan MR. 1999a. Number of generations and their duration of the lemon butterfly, (Papilio demoleus L.) in the rain fed ecology of Pakistan. Pakistan Journal of Scientific Research 51(3-4): 131-136.

- Rafi MA, Khan MR, Matin MA. 1999b. Temperature dependent development and prediction of the life stage of Papilio demoleus in the field. Pakistan Journal of Scientific Research 51(3-4): 146-150. 
- Rafi MA, Matin MA, Khan MR. 1999c.

Biology of eggs of citrus butterfly, Papilio

demoleus L. (Papilionidae: Lepidoptera).

Pakistan Journal of Science 51 (3-4): 95-99.

- Rafi MA, Khan MR, Ilyas M. 1999d. Host preference of lemon butterfly Papilio demoleus

L. in the northern Barani areas of Pakistan.

Pakistan Journal of Science 51(3-4): 93-94.

- Sherwood M, Myers L. 2008. Lime

Swallowtail, Papilio demoleus (Lepidoptera:

Papilionidae). Entomology Circular, Ministry of

Agriculture, Research and Development

Division, Jamaica.

- Tsukada E, Yasusuke N. 1982. Butterflies of the South East Asian Islands. I. Papilionidae. Plapac Co.

- Winotai A, Napompeth B. 1981. Natural enemies of the lemon butterfly, Papilio demoleus

L. (Lepidoptera: Papilionidae) in Thailand.

Proceedings of the National Conference on the

Progress of Biological Control in Thailand, National Research Council, Bangkok (Thailand). 